\title{
A ARTE COMO EXPERIÊNCIA DA INSATISFAÇÃO EM O RETRATO DE DORIAN GRAY, DE OSCAR WILDE
}

\author{
THE ART AS EXPERIENCE OF DISSATISFACTION IN \\ THE PICTURE OF DORIAN GRAY, OF OSCAR WILDE
}

Rosana Arruda de Souza*

Resumo: Discute-se, neste trabalho, sobre a obra O retrato de Dorian Gray. Levanta-se o seguinte questionamento: a deformação do retrato de Dorian seria fruto da maneira como seu receptor o lia, o interpretava? Para responder a esta questão, percorre-se o traçado das teorias literárias, fenomenologia e hermenêutica, até à estética da recepção, difundida por Wolfgang Iser. Ao longo do percurso, outras perguntas se apresentam e requerem debate como a busca do sentido autoral da obra e a transitabilidade de sentidos de uma obra artística. Chegou-se à conclusão de que a modificação do retrato resulta de um movimento de interpretações, do jogo entre o fictício e o imaginário em que o leitor se instala.

Palavras-chave: o retrato de Dorian Gray; deformação; Wolfgang Iser

Aвstract: Is discussed, in this paper, about the work The picture of Dorian Gray. Gets up the follows question: the deformation of picture of Dorian would be result of the way your receiver read it, interpreted it? To answer this question, if scrolls through the tracing of literary theories, the phenomenology and the hermeneutics, until the aesthetics of reception, broadcast by Wolfgang Iser. Over the route, other questions if show and require debates as the search for the authorial sense and the translatability of senses of an artistic work. If came to the conclusion that the modification of picture results of motion of interpretations, the match between fictitious and imaginary on what the reader settles.

KEYWORDs: the picture of Dorian Gray; deformation; Wolfgang Iser

\footnotetext{
"Mestre em estudos de linguagem e doutoranda em estudos de linguagem no Programa de Pós-Graduação em Estudos de Linguagem-PPGEL da Universidade Federal de Mato Grosso-UFMT, Campi Cuiabá. Email: rosanaarrudasouza@ hotmail.com
} 
O Retrato de Dorian Gray (1891), Oscar WILDE

Resumidamente, o referido romance trata de Dorian Gray, "um jovem de beleza invulgar" (WILDE, 2000, p. 05) retratado pelo pintor Basil Hallward. Este confessa ao amigo, Lord Henry Wotton, o desejo de não expor publicamente o retrato, porque havia posto na obra "a expressão da singular idolatria mística” (WILDE , 2000, p. 11) que sentia por Dorian. Assim, a levar o quadro à exposição, Basil prefere dá-lo de presente a Dorian.

Estimulado pelas ideias de Lord Henry, para quem o prazer e a beleza da juventude são as únicas coisas que valem a pena na vida, Dorian verbaliza o desejo de permanecer para sempre jovem, ao passo que, quem envelheceria seria seu retrato. Daria sua alma em troca disso, pois sabia que "quando se perde a beleza, seja ela qual for, perde-se tudo. Isso foi o que o seu quadro me ensinou. Lord Henry Wotton tem toda a razão. A juventude é a única coisa que vale a pena ter. Quando eu verificar que estou a envelhecer, suicido-me". (WILDE, 2000, p. 21). O desejo se torna real. O retrato se deforma, rugas aparecem-lhe, bem como a feição do rosto ganha um ar de maldade como a representar a transformação acometida pelo real Dorian que, com o passar dos anos, perde a inocência, torna-se um homem mau e chega a assassinar Basil.

A deformação do retrato seria fruto da maneira como seu receptor o lia, o interpretava? Ao longo do romance, percebemos algumas inquietações ocorridas (e talvez ainda presentes) nos estudos literários a respeito da relação autor, obra e leitor. Basil, o pintor, não quis levar sua obra a público, pois temia que percebessem nela a paixão que sentia por Dorian (o que nos remete à busca da intenção autoral que antecede a estética da recepção). O retrato, ao passar para posse de Dorian, ganha outro sentido, pois temos um novo "leitor", o próprio Dorian, daí em diante, novamente somos remetidos às questões da estética da recepção - a pintura é um espelho de Dorian, ou é o mundo empírico de Dorian que "se transforma num espelho, orientando o receptor para a concepção de algo que não existe e permitindo que esse inexistente seja visualizado como se fosse realidade" (ISER, 1999, p. 73)?

Tentativas DE INTERPRETAÇ̃̃o DE UMA OBRA ARTÍSTICA ${ }^{1}$

O retrato de Dorian Gray nos leva a refletir sobre como se interpreta uma obra e qual é o ponto de partida para tanto. Reflexão feita ao longo das várias teorias literárias que já nos apresentaram. Terry Eagleton (1997) faz um traçado dessas teorias da fenomenologia à teoria da recepção, traçado este que resenharemos agora. ${ }^{2}$

Conforme o autor, o advento das guerras mundiais provocou na arte e na vida uma

\footnotetext{
${ }^{1}$ Muito embora as teorias das quais falamos refiram-se à interpretação de obras escritas, elas também nos remetem às obras artísticas de maneira geral, como no caso da pintura, em $O$ retrato de Dorian Gray. Uma obra com linguagem não-verbal também requer uma leitura de seu receptor.

${ }^{2}$ Foi-nos de fundamental importância o artigo intitulado "Estética da recepção e teoria do efeito", de Márcia Hávila Mocci da Silva Costa, disponível em:

$<$ https://abiliopacheco.files.wordpress.com/2011/11/est_ recep_teoria_efeito.pdf $>$. Como a autora recorre a Terry Eagleton para falar sobre a estética da recepção e das teorias que a antecederam, inspiramo-nos a fazer o mesmo.
} 
perda de referências, de modo que se urgia de algo para funcionar como norte em uma sociedade onde a experiência da guerra provocara a descrença em qualquer horizonte de certezas.

[...] a ordem social do capitalismo europeu havia sido abalada em suas raízes pela carnificina da guerra e por suas turbulentas consequências políticas. As ideologias das quais essa ordem habitualmente dependera, os valores culturais pelos quais era governada, também se encontravam em estado de profunda agitação. A ciência parecia ter-se encolhido a uma posição estéril, a uma obsessão míope pela categorização de fatos; a filosofia dividia-se entre o positivismo, de um lado, e um subjetivismo indefensável de outro; predominavam formas de relativismo e irracionalismo, a arte refletia essa espantosa perda de referências. (EAGLETON, 1997, p. 75).

$\mathrm{Na}$ busca de algo em que se pudesse ter certeza, o filósofo Edmund Husserl procurou desenvolver um método que rejeitava a crença de que as coisas existiriam independentemente do ser humano. Segundo o filósofo as coisas existentes são aquelas das quais temos consciência:

Sobre o quê, então, poderemos ter certeza e ser claros? Embora não possamos ter certeza da existência independente das coisas, diz Husserl, podemos estar certos da maneira pela qual as vemos de imediato na consciência, quer seja ilusória a coisa real que estamos vendo ou não. Os objetos podem ser considerados não como as coisas em si, mas como coisas postuladas ou pretendidas pela consciência. [...]. Para termos certeza, então, devemos primeiro ignorar tudo, ou 'colocar entre parênteses' qualquer coisa que esteja além de nossa experiência imediata; devemos reduzir o mundo exterior apenas ao conteúdo de nossa consciência. (EAGLETON, 1997, p. 76).

A esse método o filósofo chamou fenomenologia, segundo o qual "as realidades devem ser tratadas como fenômenos, em termos de como eles se apresentam em nossa mente". (EAGLETON, 1997, p. 76). Nesse sentido, a fenomenologia parece algo subjetivo, a partir do momento que uma coisa é aquilo que vemos e só o é porque a vemos. Porém, o objetivo do método era exatamente o oposto:

a filosofia havia se preocupado demais com conceitos, e muito pouco com os dados reais; assim, ela havia construído sistemas intelectuais extremamente pesados sobre as mais precárias bases. A fenomenologia, tomando aquilo de que podíamos ter certeza experimentalmente, era capaz de oferecer a base para a edificação de um conhecimento autenticamente fidedigno. (EAGLETON, 1997, p. 76).

Esse modo de perceber a consciência humana como responsável pela existência das coisas provocava a centralização do mundo no sujeito, mundo este que só passa a existir a partir, então, da experiência humana. Conforme Eagleton, a fenomenologia influenciou a crítica literária, especificamente, os formalistas russos, para os quais o objeto real, na poesia, era posto entre parênteses dando lugar à maneira como era percebido. 
a crítica fenomenológica é a tentativa de se aplicar esse método às obras literárias. Como acontece no isolamento do objeto real feito por Husserl, o contexto histórico concreto da obra literária, seu autor, as condições de produção e a leitura são ignorados. A crítica fenomenológica visa a uma leitura totalmente 'imanente' do texto, absolutamente imune a qualquer coisa fora dele. O próprio texto é reduzido a uma pura materialização da consciência do autor [...]. Para conhecê-la, não devemos nos referir a nada que sabemos sobre o autor - a crítica biográfica é proibida - mas tão somente aos aspectos de sua consciência que se manifestaram na obra em si. (EAGLETON, 1997, p. 81).

A crítica fenomenológica deixava uma lacuna referente à produção de sentidos de uma obra. Se, segundo a fenomenologia, o válido é o que está sendo visto e captado por nossa consciência, temos um papel, na verdade, passivo. Se o existente é o que estamos vendo, não somos incitados, então, a produzir ou a querer algo a mais. O que estamos vendo pode ser apenas uma imagem; a produção de sentidos de algo passa a ocorrer quando queremos ver o que está por trás da imagem, ou melhor, que resultado veríamos contrapondo esta imagem a outras. Entendemos que ver um texto por esta perspectiva é reduzir a própria natureza prática do olhar que vê o que está à frente, mas também é movido por reflexos, captando eventos ou sombras de eventos laterais.

[...] a crítica fenomenológica tenta obter a total objetividade e o completo desinteresse. Ela deve se purgar de suas próprias predileções, mergulhar empaticamente no 'mundo' da obra e reproduzir o mais exata e imparcialmente possível o que nela encontra. Se vier a se ocupar de um poema cristão, ela não deve se interessar em formular juízos de valor sobre esta visão do mundo específica, mas demonstrar o que terá sido para o autor 'vivê-la'. (EAGLETON, 1997, p. 82, grifo nosso).

Assim, por mais que, como foi dito anteriormente, numa crítica fenomenológica nos abstenhamos de pesquisar sobre o autor para entender a obra, deduzimos que, ainda assim, o que será visto na obra é tal qual o autor produziu, uma vez que ao passar da produção para recepção, não houve construção de sentidos.

Concebemos a linguagem como o objeto utilizado para construir a imagem que queremos passar ao outro e também a imagem que o outro nos passa, dessa forma, numa crítica fenomenológica, em que não há essas construções, perguntamos onde fica o papel da linguagem. Conforme Eagleton (1997, p. 83) "a característica da revolução linguística do séc. XX, de Saussure e Wittgenstein até a teoria literária contemporânea, é o reconhecimento de que o significado não é apenas alguma coisa 'expressa' ou 'refletida' na linguagem - é na realidade produzido por ela”. Para o autor, a fenomenologia de Husserl sacrifica a própria história humana onde os significados são construídos historicamente nas relações sociais.

A favor do conhecimento histórico, Martin Heidegger, discípulo de Husserl, rompeu com o pensamento do mestre, lançando 
o que chamou de hermenêutica do ser. Para Heidegger, a existência humana

é em primeiro lugar sempre o ser no mundo: só somos sujeitos humanos porque estamos praticamente ligados ao nosso próximo e ao mundo material [...]. O entendimento não é, em primeiro lugar, uma 'cognição' isolável, um ato particular que pratico, mas parte da própria estrutura da existência humana. (EAGLETON, 1997, p. 85, 86).

Compreendemos, pelos comentários feitos por Eagleton a posteriori, que Heidegger radicalizou a questão do sentido da obra ser produzido pela linguagem. Porque, para o filósofo, a linguagem não parte de nós enquanto sujeitos, mas enquanto seres no mundo, de modo que o significado a que chegamos de uma obra nunca será individual, mas partirá de um pré-entendimento já existente no mundo. "A arte, como a linguagem, não deve ser considerada como a expressão de um sujeito individual: o sujeito é apenas o local, ou o meio, pelo qual a verdade do mundo se manifesta, e é essa verdade que o leitor de um poema deve ouvir atentamente". (EAGLETON, 1997, p.89).

Um dos sucessores de Heidegger foi o alemão Hans-Georg Gadamer que compactuava com as ideias do primeiro, ao menos quanto ao significado histórico da obra. No entanto, na perspectiva de Gadamer, a hermenêutica não remete a uma impossibilidade de flexão de sentidos de uma obra, mas sim ao fato da inexistência de uma nossa explicação para uma obra, porque esta sempre vai estar influenciada por aspectos de referência históricos ou culturais. Nesse sentido, se muda o contexto histórico em que estamos inseridos, muda o sentido da obra, embora não seja nossa leitura, enquanto sujeitos individuais, responsável por isso, mas sim a leitura do ser no mundo situado historicamente:

Para ele [Gadamer], o significado de uma obra literária não se esgota nunca pelas intenções do seu autor; quando a obra passa de um contexto histórico para outro, novos significados podem ser dela extraídos, e é provável que eles nunca tenham sido imaginados pelo seu autor ou pelo público contemporâneo dele. [...]. Gadamer não se preocupa com a possibilidade de que nossos preconceitos culturais tácitos, ou 'pré-determinados', venham prejudicar a recepção da obra literária do passado, já que esses pré-entendimentos nos vêm da própria tradição, da qual a obra literária é parte. (EAGLETON, 1997, p. 98, 99).

Concluímos que, tanto na fenomenologia de Husserl quanto na hermenêutica de Heidegger, não se focaliza um papel ativo do sujeito na leitura de uma obra literária. $\mathrm{Na}$ fenomenologia tínhamos a essência do objeto captada pela consciência humana, mas essa percepção das "coisas em si mesmas" (Eagleton 1997, p. 79) é um ato falho, incompleto. Possivelmente, o modo para captar a essência (se esta existe) de um objeto ou de uma obra literária seria, na verdade, começar vendo-o pelo que ele não é.

Já na hermenêutica, tínhamos o reconhecimento de que o significado é histórico ou, como disse Gadamer, faz parte de uma tradição. Assim, a explicação de uma dada 
obra pode a até mudar de tempos em tempos, mas a nossa explicação sempre será a mesma do próximo uma vez que estamos inseridos em uma mesma tradição. Eagleton questiona de que tradição e de quem Gadamer tinha em mente e que "sua teoria só é válida na suposição de só haver realmente uma tradição 'principal'; de que todas as obras 'válidas' dela participam; [...]”. (EAGETON, 1997, p. 100).

A terceira teoria literária discutida por Eagleton é a estética da recepção ou teoria da recepção que "examina o papel do leitor na literatura” (EAGLETON, 1997, p. 102). Deixaremos para descrevê-la na seção seguinte, à medida que formos tratando do nosso objeto de análise, O retrato de Dorian Gray. Por ora, citaremos um trecho sobre a teoria da recepção, no qual entrevemos o mote que nos levou a discutir sobre esse objeto:

Para Iser, a obra literária mais eficiente é aquela que força o leitor a uma nova consciência crítica de seus códigos e expectativas habituais. A obra interroga e transforma as crenças implícitas com as quais a abordamos, 'desconfirma' nossos hábitos rotineiros de percepção e com isso nos força a reconhecê-los, pela primeira vez, como realmente são. [...]. Se modificamos o texto com nossas estratégias de leitura, ele simultaneamente nos modifica: como os objetos de um experimento científico, ele pode dar uma 'resposta' imprevisível às nossas 'perguntas'. (EAGLETON, 1997, p. 108).
Uma análise de O retrato de Dorian GRAY

Quando Basil Hallward é perguntado por Lord Henry Wotton por que não queria levar o retrato que acabara de pintar a uma exposição, dá como justificativas:

[...] não posso expô-lo. Pus nele demasiado de mim mesmo.

[...], todo retrato pintado com sentimento é um retrato do artista, e não do modelo. O modelo é apenas o acidente, o pretexto. O pintor não o revela a ele, o pintor é que revela a si mesmo na tela colorida. O motivo por que não exponho este quadro é o medo de que eu tenha revelado nele o segredo da minha alma.

$[\ldots]$.

Porque, involuntariamente, pus nele um pouco da expressão desta idolatria mística, de que, evidentemente, nunca me interessou falar-lhe. Ele não sabe nada disto. Nem nunca saberá. O público, porém, poderia descobrir, e eu não quero desnudar a minha alma à sua curiosidade grosseira. (WILDE, 2000, p. 06, 07, 11).

Muito embora o conceito de interpretação literária em voga (ou mais utilizado, pelo menos, nos meios acadêmicos) seja aquele que leva em conta o papel do leitor, temos interesse na maneira como Basil via o objeto como expressão do autor, como se o objeto trouxesse uma essência autoral. Além disso, Wolfgang Iser nos diz como as velhas teorias sobre interpretação literária são importantes na medida em que não se apagam, mas são o que nos permitem entrever novos estudos: 
[...]. É indiscutível, porém, o seguinte traço fundamental na história da interpretação: as questões formuladas anteriormente não deixam de exercer influência quando novas questões estão sendo concebidas. [...]. As respostas anteriores não estão mortas e enterradas, mas sobrevivem como fontes negativas para que novas perguntas sejam feitas. Assim, a intenção do autor, a mensagem da obra, o valor manifestado na conciliação harmoniosa, todos estes critérios constituem o pano de fundo para a teoria do efeito estético. (ISER, 1999, p. 24).

O modo como Basil via sua obra de arte nos remete à fenomenologia de Husserl segundo a qual o nosso olhar deve captar a essência universal de um objeto: "a fenomenologia examinava não apenas o que por acaso se percebesse quando se olhasse para um determinado coelho, mas a essência universal dos coelhos [...]" (EAGLETON, 1997, p. 78). E, em se tratando de uma obra artística, a essência a ser captada é o sentido de sua origem, no caso, o sentido que o autor lhe conferiu no ato de produção: "segundo tal interpretação, o significado ou sentido de uma obra literária é fixado de uma vez por todas: ele é idêntico a qualquer 'objeto mental' que o autor teve em mente, ou 'pretendeu' ter no momento de escrever". (EAGLETON, 1997, p. 92).

Basil não contava com o fato de que cada um que visse o retrato poderia interpretá-lo de maneira particular e, mesmo que o receptor tivesse a oportunidade de ouvi-lo sobre a profunda admiração que sentia por Dorian, ainda assim, o receptor poderia continuar interpretando o retrato de outra forma. Por que dizer que a audição das pretensões de um autor sobre sua obra devem nos levar a uma aceitação tácita? Mesmo Lord Henry, que pessoalmente ouviu Basil dizer que o retrato revelava a alma do autor, não aceitou essa justificativa: "creio que você não tem razão, Basil. Mas não quero discutir consigo. Só os intelectualmente perdidos é que discutem" (WILDE, 2000, p. 11).

"Husserl sugeria que ser e significar estão sempre atados um no outro. Não há objeto sem sujeito, e não há sujeito sem objeto" (EAGLETON, 1997, p. 79). Já E. D. Hirsch Jr., um hermeneuta americano, separava sentido de significação. Para ele, uma obra pode ter várias interpretações, no entanto, seu sentido é único, acabando por se assemelhar à opinião de Husserl:

Para Hirsch, o fato de o significado de uma obra ser idêntico ao que o autor entendeu por ela no momento de escrever, não implica uma única interpretação do texto. Pode haver várias interpretações diferentes e válidas, mas todas elas devem se situar dentro do 'sistema de expectativas e probabilidades típicas' que o sentido do autor permitir. Hirsch também não nega que uma obra literária possa 'significar' diferentes coisas para diferentes pessoas em diferentes épocas. Mas isso, diz ele, é antes uma questão da significação da obra do que do seu sentido. [...]. As significações variam ao longo da história, ao passo que os sentidos permanecem constantes; os autores dão sentido às suas obras, ao passo que os leitores atribuem significações. (EAGLETON, 1997, p. 92). 
É interessante como Hirsch parece desconsiderar como o autor pode ser o próprio leitor de sua obra e lhe atribuir também uma significação. Como veremos adiante, quando o quadro já está deformado, Dorian permite que Basil o veja. O que leva Basil ao reconhecimento de sua própria obra não é mais aquela ideia de essência autoral que ele tinha no início, o reconhecimento é feito de maneira bem material e objetiva, pela assinatura do autor, que é visível no canto esquerdo da tela e pela moldura, que ele mesmo desenhara e mandara fazer.

Além disso, Hirsch não esclarece o que entende por sentido da obra. Se não é algo que podemos ouvir de seu autor, como Lord Henry o pôde; se não é algo materializado na página ou, no caso, na tela; como podemos conceber o sentido de uma obra dado pelo autor? Para Eagleton (1997, p. 92, 93),

ao identificar o sentido de um texto com aquilo que o autor entendeu por ele, Hirsch não presume que tenhamos sempre acesso às intenções do autor. Ele pode estar morto, ou pode ter esquecido o que queria dizer. Seguese que por vezes podemos chegar à interpretação 'correta' de um texto, mas nunca estaremos em condições de sabê-lo. Isso não preocupa Hirsch, desde que seja mantida a sua posição básica - a de que o sentido literário é absoluto e imutável, resistente à mudança histórica. Ele pode sustentar essa posição básica porque sua teoria do sentido, como a de Husserl, é pré-linguística. O sentido é algo que o autor quer, é um ato mental, espiritual, que é então 'fixado' para todo o sempre através de uma série particular de sinais materiais. Trata-se de uma questão de consciência e não de palavras. De que consiste exatamente essa consciência sem palavras, o autor não deixa claro.

Além da questão autoral, O retrato de Dorian Gray nos remete a um fator muito interessante da produção de uma obra artística, vista na perspectiva da teoria da recepção - o fato de que, se nós somos capazes de modificar o texto, nós também somos modificados por ele. “Toda a função da leitura é, para um crítico como Iser, levar-nos a uma autoconsciência mais profunda, catalisar uma visão mais crítica de nossas próprias identidades" (EAGLETON, 1997, p. 109). É claro que, por modificar o texto, entendemos criar novos sentidos para o mesmo, no entanto, Iser nos fala que isso foi levado ao extremo nos primórdios da estética da recepção quando chegaram a indagar: "uma vez encontrado, por que o sentido haveria de mudar, se as letras, as palavras e as frases do texto permaneciam as mesmas?" (EAGLETON, 1997, p. 22, grifo nosso). Agora, atrevemo-nos a perguntar algo semelhante - se é apenas o sentido que muda e não a obra em si, por que o retrato de Dorian Gray se deformou? Houve no retrato mudanças não só na maneira como era interpretado, mas no próprio objeto, na pintura em si.

Possivelmente, encontramos a resposta no imaginário desencadeado no ato de leitura. Destacam-se, na obra, dois objetos - o retrato e a imaginação de Dorian. Dizemos a imaginação de Dorian, pois a deformação do quadro começa quando cai na posse do jovem e é a sua imaginação que parece se pôr entre 
o retrato e a vida empírica. Ao mesmo tempo, como é o quadro o meio pelo qual a imaginação se desenrola, pois funciona como campo de expectativas a partir das quais Dorian parte para experiência, não dá para saber, afinal de contas, o que está sendo imagem de quê, o quadro reflete a vida ou esta que o reflete. Vejamos o momento em que o quadro se abre como mundo de expectativas para Dorian, que começa a perder a ingenuidade, a se embeber nas teorias hedonistas de Lord Henry e a querer experimentar os prazeres da vida:

Passou distraidamente diante do quadro e virou-se de frente para ele. Quando o viu, recuoue, por momentos, o rosto ruburizou-se-lhe de satisfação. Assomou-lhe aos olhos uma expressão de júbilo, como se tivesse se reconhecido pela primeira vez. [...]. A sensação da sua própria beleza surgiu-lhe como uma revelação. Nunca a sentira antes. Os elogios de Hallward pareceram-lhe sempre amáveis exageros provenientes da amizade que os unia. Escutara-os, rira-se deles e, depois, esquecera-os. Nunca haviam exercido nele qualquer influência. Depois, aparecera Lord Henry Wotton com o seu estranho discurso panegírico sobre a juventude e o prenúncio terrível de sua brevidade. Isso perturbara-o então, e agora, ao encarar o reflexo da sua beleza, toda a realidade da descrição acudiu-lhe subitamente ao espírito. De fato, havia de chegar o dia em que o rosto ficaria enrugado e mirrado, os olhos baços e sem cor, e a graciosidade das suas formas destruída e deformada. (WILDE, 2000, p. 20).
A cena descrita se refere ao momento imediato em que Dorian vê-se em seu retrato depois de pronto. Em seguida, o jovem faz o desejo da juventude eterna em troca de sua própria alma. Entre o recebimento do quadro como presente e o início da deformação da pintura, Dorian se apaixona por Sibyl Vane, uma jovem atriz de teatro não famosa, mas que Dorian achava que logo iria sê-lo, pois interpretava muito bem. No entanto, no dia em que leva ao teatro seus amigos Basil e Henry, a atriz atua de maneira desprezível. Dorian termina a relação com a moça, pois havia se apaixonado pelas belas representações que fazia, sem a arte, ela não valia mais nada. Sibyl tenta explicar que representara mal naquela noite propositalmente, pois queria mostrar para o amado que, até o conhecer, sua vida era os palcos, porém o rapaz havia-lhe ensinado o prazer da vida real. Dorian não entende as boas intenções da moça e a deixa só. Quando chega a casa, ao atravessar a biblioteca em direção ao quarto:

os olhos depararam com seu retrato pintado por Basil Hallward. Recuou sobressaltado, como que surpreendido. Em seguida, um pouco perplexo, foi entrando para o quarto. Depois de ter retirado a botoeira do casaco, pareceu hesitar. Por fim, voltou atrás, aproximou-se do retrato e examinou-o. À fraca claridade da luz que conseguia passar através dos estores de seda creme, afigurava-se-lhe um pouco alterado. A expressão estava diferente. Dirse-ia que havia um laivo de crueldade na boca. (WILDE, 2000, p. 62).

Conforme a teoria da recepção, a construção (produção/leitura) de uma obra nos 
envolve em atos de fingir. "Como leitores, estamos assim enredados no texto, sendo simultaneamente capazes de observar a nós mesmos nesse enredamento". (ISER, 1999, p. 66). Ainda segundo essa teoria, a literatura seria por si só um fingimento, em que conta-se o que não é como se fosse; ao mesmo tempo, o ato de fingir é algo extremamente ambíguo e paradoxal - se a coisa se trata de um fingimento, podemos também suspeitar da literatura como um espaço em que conta-se o que é, sim, como se não fosse.

Segundo Iser, os atos de fingir abrangem a seleção, a combinação e o autodesnudamento. A seleção é o momento de captação de realidades referenciais que são suspensas, postas entre parênteses e invalidadas, passando a valer o modo como são percebidas no texto. Na teoria de Husserl, o mundo também era posto entre parênteses, no entanto, agora, temos o papel ativo do sujeito que participa do fingimento. Na combinação, os dados referenciais em suspensão são combinados com elementos que permitam a transgressão ou a criação de possibilidades em relação ao mundo suspenso: "[...], a combinação confronta o dado à alteridade. Ao serem transgredidas posições estabelecidas no texto, dado e alteridade se convertem em possibilidades um para o outro. [...]. O significado literal, representacional permanece latente como uma orientação para o que deve ser concebido dali em diante". (ISER, 1999, p. 72). O autodesnudamento, por sua vez, "assinala que o mundo do texto não é de fato um mundo, mas para fins específicos deve se considerado como tal." (ISER, 1999, p. 72).
Agora, vislumbrando os atos de fingir no retrato de Dorian, inferimos que o referente selecionado por Basil foi a beleza do rapaz. Até então, o jovem só havia pousado para Basil representando personagens: "eu desenhara-o como Páris, numa elegante armadura, e como Adónis, com a capa de caçador e empunhando uma reluzente lança. Coroado de pesadas flores de lótus, sentara-se à proa da barca de Adriano, a contemplar as águas verdes e turvas do Nilo". (WILDE, 200, p. 77). Um dia, Basil decidiu representar o jovem tal como era, sem roupagens do passado, usando o próprio trajado e à moda da sua época. No entanto, a partir do momento em que os referentes selecionados foram suspensos e combinados com outros e, assim, transformados em arte, não podemos ver o retrato como o espelho da realidade, mas como uma transgressão desta.

Basil confessa, ao amigo Henry, que o modelo de seu quadro fora "apenas o acidente, o pretexto. $O$ pintor não o revela a ele, $o$ pintor é que revela a si mesmo na tela colorida" (WILDE, 2000, p. 07). No entanto, aqui, concebemos Dorian como o referencial que Basil usou e, de fato, foi apenas o pretexto, o acidente, porém, não para que o autor revelasse a si, mas para que, daí em diante, por meio da combinação, o como se da arte criasse "um espaço entre o mundo empírico e a sua transformação em metáfora para o que permanece não dito". (ISER, 1999, p. 70).

Assim, inicia-se um jogo entre o fictício e o imaginário, conforme o diz Iser. Nesse sentido, encaramos imaginário não apenas como referente ao ato de imaginar, mas imaginário enquanto proveniente de imagens, 
ao conjunto ou jogo de imagens em que o receptor se envolve. Husserl chamava de fantasia o que Iser preferiu chamar de imaginário, "uma vez ativada a fantasia, o que é não pode permanecer o mesmo”. (ISER, 1999, p. 71). Em O retrato de Dorian Gray, o que era não continuou sendo, nem no retrato, nem na vida, onde se buscou um referencial. No trecho anteriormente citado, em que Dorian se vê diante do retrato pronto, percebemos como o imaginário é ativado pelo fictício Dorian percebe que a imagem e os elogios que o pintor fazia à sua beleza, não eram, até então, a imagem que o próprio Dorian fazia de si; o retrato é quem o ensina a ser vaidoso.

Depois que Dorian percebe a primeira alteração no retrato, esconde-o, colocando em sua frente um grande biombo, que passa a servir como um elemento importante neste jogo entre fictício e imaginário. "Mas o que aconteceria se, por um acaso do destino ou fatalidade, outros olhos que não os seus espreitassem por detrás do biombo e vissem a medonha transformação?” (WILDE, 2000, p. 65). Esse biombo fica sendo uma espécie de fronteira entre o retrato e a vida, um peso que Dorian toda vez tinha que mover para contemplar-se no retrato:

Contemplá-lo seria, pois, um verdadeiro prazer. Poderia perscrutá-lo até aos seus mais secretos recantos. Este retrato seria para si o mais mágico de todos os espelhos. Assim como lhe revelara o próprio corpo, haveria de revelar-lhe a alma. E quando o inverno descesse sobre o retrato, ele estaria ainda onde a primavera vacila à beira do verão. Quando o sangue lhe abandonasse o rosto, deixando atrás de si uma lívida máscara de giz com olhos plúmbeos, ele conservaria o encanto da mocidade. Nenhuma flor da sua formosura haveria de murchar. [...]. Que importava o que acontecia à imagem colorida da tela? Ele não correria perigo. [...]. Arrastou o biombo novamente para o lugar habitual à frente do retrato, [...]. (WILDE, 2000, p. 72).

O biombo funciona também como o contratempo $\mathrm{p}^{3}$ o adiamento na história que segreda a nódoa no retrato, ou como Dorian chamava, a sua alma. Em um momento da história, Basil muda de ideia e vai à casa de Dorian dizer-lhe que quer o retrato para expô-lo em Paris. É interessante como a mudança de ideia de Basil veio depois que o retrato saiu de sua posse, como que, findada uma leitura, o seu olhar de leitor, se abrisse para um novo mundo de possibilidades e novas relações entre o fictício e o imaginário pudessem se realizar. Então, disposto a uma segunda leitura do retrato, Basil compreende:

[...], assim que me libertei do intolerável fascínio da sua presença [do retrato], achei que fora tolo ao imaginar que vira nele alguma coisa mais para além do fato de que você era extraordinariamente bem parecido e que eu sabia pintar. [...]. Muitas vezes afigura-se-me que a arte esconde o artista muito

\footnotetext{
${ }^{3}$ Jacques Derrida (2014, p. 31) conceitua o contratempo como a relação entre o acaso e o destino, a existência de uma combinação, um jogo, entre o acaso e a determinação, visto que o aleatório interfere o tempo todo e das mais imprevisíveis maneiras no decurso do próprio tempo. Como exemplo, cita a carta, em Romeu e Julieta, que não chega a tempo para revelar o plano forjado.
} 
mais do que o revela. (WILDE, 2000, p. 77,78$)$.

Entre o fictício e mais um receptor a ter o imaginário (re)ativado, o biombo funciona como o contratempo que Basil não consegue ultrapassar. Ao receber de Dorian o aviso que nunca mais lhe serviria de modelo, Basil se irrita é quer tomar para si o retrato: "que disparate, meu rapaz! - gritou ele. Pretende dizer que não gosta do retrato que lhe fiz? Onde está? Por que colocou o biombo diante dele? Deixe-me vê-lo. É a melhor coisa que já fiz. Afaste o biombo, Dorian. [...]”. (WILDE, 200, p.75). Dorian se põe entre Basil e o biombo e, depois de muita conversa, faz o amigo desistir da ideia de levar o quadro à exposição. Até, aqui, não ficamos sabendo se um segundo receptor leria o mesmo laivo de crueldade no retrato, como Dorian o lera.

Depois da visita de Basil, Dorian decide tirar o retrato da biblioteca e pô-lo em um velho quarto de estudos, no último andar da casa. Porém, como o retrato era um tanto pesado e teria de subi-lo pela escadaria, decide pedir o auxílio de um moldureiro e seu ajudante. Para que estes deslocassem o retrato sem descobrirem o que nele havia, Dorian o envolve em uma suntuosa colcha de cetim cor de púrpura bordada a ouro. É interessante como o referido quarto era também o lugar que servira de esconderijo para Dorian quando criança. Seu avô mandara construir o cômodo especialmente para o menino, pois, por achá-lo extremamente parecido com a mãe, com quem havia tido desavenças, queria mantê-lo à distância.

Os anos passam e Dorian começa a ser alvo de difamações devido ao estranho estilo de vida que leva. No entanto, sua beleza permanece impoluta, bem como o hábito de contemplar sua imagem no quadro, agora de forma quase ritualística:

ao regressar a casa, depois de uma dessas misteriosas e prolongadas ausências que originavam aquelas insólitas conjecturas entre os amigos, ou que julgavam sê-lo, costumava, com frequência, subir silenciosamente até o quarto trancado, abrir a porta com a chave que trazia agora sempre consigo, e, com um espelho, ficar frente a frente do retrato que dele fizera Basil Hallward, olhando ora o rosto maligno e envelhecido da tela, ora o jovem rosto formoso que lhe devolvia o sorriso na superfície polida do espelho. (WILDE, 2000, p. 86).

No jogo do fictício e imaginário, a realidade cancelada permanece ali, apenas em um estado de anulação, isso permite que o sujeito enredado no fingimento consiga observar a si mesmo. A esse momento em que o que é negado resulta no próprio ato de admissão, pois o que foi anulado ainda está presente, Iser denomina de negação: "ao negar a validade do segmento selecionado, ela[a negação] recorda o seu sentido anterior e assinala a motivação não verbalizada, subjacente ao próprio ato de negar e responsável pelo seu direcionamento" (ISER, 1999, p. 31). No caso do retrato de Dorian, a realidade referencial posta entre parênteses, a princípio, é a beleza do jovem retratada, porém, a partir do momento que esse referencial é combinado com outros elementos e que o imaginário é ativado, a realidade é excedida e ganha um novo sentido - agora, não se trata mais da 
bela figura de um jovem, mas sim o retrato de sua alma. No entanto, o leitor tem consciência que a realidade anulada ainda está ali e pode, por que não, ser reativada, uma vez que "o que é revelado aparece como um sinal do que permanece encoberto". Dorian via sua imagem envelhecida no retrato, mas sabia que sua outra imagem permanecia ali - "era certo que, debaixo da sordidez e fealdade, o retrato mantinha uma acentuada parecença consigo, mas que poderiam daí concluir? Ele rir-se-ia de quem quer que tentasse escarnecer. Não fora ele que o pintara". (WILDE, 2000, p. 94).

O tempo passa e Dorian chega aos trinte e oito anos de idade. Basil vai novamente ao seu encontro. Dessa vez, estava de partida para Paris onde iria ficar por seis meses, mas, antes, precisava alertar Dorian das coisas horríveis que andavam a dizer dele em Londres. Segundo os comentários que Basil ouvira, o rapaz manchara a reputação de seus amigos, que haviam perdido o sentido de honra, de bondade e pureza e que um desses amigos chegara a suicidar-se devido às influências de Dorian. Basil diz não reconhecer mais o amigo e que teria de ver a sua alma para poder mensurar o que ele era e no que se transformou. Dorian pede que o pintor o acompanhe ao andar de cima da casa, lá Basil veria sua alma - "registro dia a dia o diário da minha vida, e nunca sai do quarto em que o escrevo. Posso mostrar-lhe se vier comigo". (WILDE, 2000, p. 102). Quando Basil se depara com o retrato podemos mensurar o quanto a imagem retratada se modificara ao passo que, até agora, havíamos tido um ideia pouco detalhada disso, outrora Dorian falara apenas de uma sordidez e fealdade na imagem.

o artista gritou horrorizado, quando viu, na semiobscuridade, a face hedionda da tela que para ele sorria com um esgar. Havia qualquer coisa naquela expressão que lhe provocava repulsa e nojo! Deus do Céu! Tinha mesmo à sua frente a cara de Dorian Gray! O horror, por muito grande que fosse, não completara os seus estragos naquela beleza deslumbrante. Havia ainda reflexos dourados no cabelo ralo e um vivo rubor na boca sensual. Os olhos mortiços haviam conservado um pouco da beleza do azul, e não se havia desvanecido toda a nobreza das curvas perfeitas das narinas e da flexibilidade do pescoço. Sim, era Dorian, sem dúvida. Mas quem fizera aquilo? Parecia reconhecer as suas pinceladas, e a moldura era a que ele desenhara. Era uma ideia monstruosa, mas não deixava de sentir medo. Pegou na vela acesa e aproximou-se do retrato. No canto esquerdo da tela via-se o seu nome, em grandes letras traçadas a vermelhão vivo. (WILDE, 2000, p. 103).

Quando Basil se depara com a deformação de sua arte parece não reconhecê-la como sua, precisando voltar-se para moldura e para sua assinatura. No entanto, desde o primeiro momento reconhece que era, sim, a imagem de Dorian, pois a deformação não encobrira totalmente os traços de beleza do rapaz. Como já mencionamos, no ato de combinação o mundo empírico transforma-se em metáfora para o que permanece encoberto. Quando nos voltamos para o retrato, percebemos que, de fato, ele não é 
espelho da realidade e nem metáfora desta, mas esta que metaforiza o retrato, é esta que está servindo para acentuar toda a maldade descrita ali. Iser (1999, p. 70) diz "metáfora para o que permanece encoberto" - apesar da imagem está encobrindo os resquícios de beleza que o jovem tinha, o que permanece encoberto, paradoxalmente, é a crueldade e o envelhecimento de Dorian. Esta é a negação que nega admitido, da qual nos fala Iser. A imagem cruel e envelhecida do retrato é a negação e não a afirmação do que Dorian se tornara em sua vida empírica, uma vez que o retrato em nada poderia provar as tais coisas cruéis que Basil ouvira a sociedade falar do amigo. Tanto é que, antes de revelar o retrato a Basil, Dorian o provoca dizendo: "Venha: é a obra feita pelas suas próprias mãos. Por que não contemplá-la? Depois pode falar dela ao mundo, se quiser. Ninguém iria acreditar em si. Se acreditassem ficariam ainda mais a gostar de mim" (WILDE, 2000, p. 101). Ou seja, o retrato de Dorian o mostra, mas ao mesmo tempo o nega, por isso o rapaz acredita que, mesmo aqueles que soubessem da deformação de sua imagem no retrato, o tomariam como motivo para adorá-lo, e não para odiá-lo. Assim, corroboramos com Iser quando diz:

a obra literária não deve ser considerada um registro documental de algo que existe ou já existiu, mas antes uma reformulação de uma realidade identificável, reformulação que introduz algo que não existia antes.

[...].

A literatura traz para o mundo algo que não estava lá antes. Esse algo precisa revelar-se para ser compreendido. Todavia, como os elementos estranhos não podem manifestar-se sob as condições vigentes no caso da manifestação de concepções familiares ou já existentes, o que a literatura traz para o mundo só pode revelar-se como negatividade. (ISER, 1999, p. 21, 32,33).

Percebemos então, que houve uma flexibilização de interpretações do retrato de Dorian. Basil o interpretava de uma forma e, agora, depois de muitos anos, quando volta a vê-lo se assusta e parece compartilhar da interpretação de Dorian. Isso nos remete ao que Eagleton diz do processo de leitura de uma obra literária em uma perspectiva da teoria da recepção:

a leitura não é um movimento linear progressivo, uma questão meramente cumulativa: nossas especulações iniciais geram um quadro de referências para a interpretação do que vem a seguir, mas o que vem a seguir pode transformar retrospectivamente o nosso entendimento original, ressaltando certos aspectos e colocando outros em segundo plano. (EAGLETON, 1997, p. 106).

Eagleton também argumenta que a teoria da recepção permite que diferentes leitores tenham liberdade de concretizar a obra de diferentes maneiras. No caso de Basil e Dorian, se houve coincidência na maneira como viram o retrato, atribuímos isso ao fato de estarem inseridos no mesmo contexto histórico. Assim, um leitor, fora das condições em que Basil e Dorian se encontravam, poderia ver a mesma "figura grácil, formosa, que com tanta perfeição Basil registrara através 
de sua arte". (WILDE, 2000, p. 05). Para Iser (1999, p. 20),

a recepção diz respeito ao modo como os textos têm sido lidos e assimilados nos vários contextos históricos. Procurando mapear as atitudes que determinaram certo modo de compreensão dos textos numa situação histórica específica, o estudo da recepção depende, de forma quase exclusiva, das evidências disponíveis.

Essa consideração de Iser nos faz compreender o desenrolar do romance $O$ retrato de Dorian Gray. Após Dorian ter revelado a Basil o retrato deformado, o mata a facadas impulsionado por "um desenfreado sentimento de ódio por Basil Hallward, como se lhe houvesse sido sugerido pela imagem da tela, [...]". (WILDE, 2000, p. 105). No dia seguinte, quando voltou a olhar a tela, percebeu que luziam em uma das mãos gotas vermelhas, cintilantes e úmidas. Dorian consegue livrar-se do corpo e o assassinato nunca fora descoberto. O tempo passa e o rapaz é acometido de certo arrependimento: "que monstruoso momento de soberba e paixão aquele em que suplicara que fosse o retrato a carregar o fardo dos seus dias, [...]. Teria sido melhor para ele que cada pecado de sua vida trouxesse o castigo firme e imediato. $\mathrm{O}$ castigo purificava." (WILDE, 2000, p. 147). Dorian começa a praticar boas ações, mas quando percebe que sua mudança de caráter não provoca nem uma alteração no retrato, suicida-se. Quando entraram no quarto, os criados

viram pendurado na parede um magnífico retrato do seu amo, tal como era quando o viram a última vez, em todo o fulgor da sua deslumbrante juventude e beleza. No chão, jazia um homem morto, em trajo de cerimônia, com uma faca cravada no coração. Estava mirrado, enrugado e tinha uma cara repugnante. Examinaram-lhe os anéis, e só então o reconheceram. (WILDE, 2000, p. 149).

Poderíamos compreender a imagem que os criados viram no quadro como a concretização do poder sobrenatural, o mesmo que teria tornado real o desejo de eterna juventude, agora, modificara novamente o retrato, que voltou a ser o que era, para atender ao arrependimento de Dorian. No entanto, lançando mão da teoria da recepção, encaramos que o retorno da imagem do retrato às origens, como Basil o havia concebido, se deve a mais uma interpretação resultante do jogo entre fictício e imaginário. Dessa vez, os leitores são os criados. Por que eles não viram a mesma imagem enrugada digna de repulsa que Basil viu antes de ser assassinado? Como vimos anteriormente, a teoria da recepção considera a interpretação de uma obra literária em uma determinada situação e, além disso, o jogo entre o fictício e imaginário não é independente dos referenciais da realidade, estes são anulados, mas permanecem como pano de fundo para o imaginário:

[...]. A modificação principia portanto a desdobrar-se com um ato anulador para o qual o mundo referido é indispensável, uma vez que se trata de salientar o que perdeu status de realidade-os campos referenciais, os itens combinados no texto, além do próprio 
mundo representado no texto e dessa forma posto entre parênteses. [...].

O que foi invalidado - todo o espectro dos campos referenciais - é relegado ao passado, e a motivação para tal mudança torna-se o novo presente. Este só pode ser imaginado contra o pano de fundo constituído por aquilo que foi cancelado, pois tais atos de imaginação seriam impossíveis sem se recorrer aos sistemas de referência invalidados. (ISER, 1997, p. 71, 72, grifo nosso).

A interpretação, então, demanda de evidências disponíveis que direcionem o leitor e que sirvam de meio para o imaginário. Basil já provinha dessas evidências antes de visualizar a deformação do retrato, uma vez que fora à casa de Dorian justamente para falar da figura cruel em que se transformara segundo os comentários que ouvira sobre o rapaz. Assim, o receptor de agora não é o mesmo de anos atrás que tinha como referencial a beleza e inocência do jovem Dorian. Agora ele lidava com um Dorian vaidoso e pervertido pelo tempo, bem como pelas ideias hedonistas de Lord Henry. Será que os criados dispunham dessas mesmas evidências? Além disso, outro aspecto da teoria da recepção nos norteia a uma explicação de que nem todos os leitores fariam a mesma interpretação que Basil e Dorian fizeram do retrato:

o humanismo liberal de Iser, como a maioria dessas doutrinas, é menos liberal do que parece à primeira vista. Ele diz que um leitor com fortes compromissos ideológicos provavelmente será um leitor inadequado, já que tem menos probabilidade de estar aberto aos poderes transformativos das obras literárias. Isso deixa implícito que para sofrermos uma transformação às mãos do texto, devemos em primeiro lugar ter convicções muito provisórias. (EAGLETON, 2000, p. 109).

Em seguida, Eagleton interpela a ideia de Iser, dizendo que, se as convicções do leitor forem tão superficiais assim, seu questionamento e subversão pelo texto não serão realmente muito significativos. Apesar disso, corroboramos com Iser, pois podemos pensar em Dorian e Basil como figuras sem fortes convicções. Perguntamo-nos se Lord Henry, considerado um homem com forte poder de influenciar os outros, veria a deformação no retrato. Além disso, a mudança de caráter sofrida por Dorian não era, para Henry, um defeito, muito pelo contrário, achava-lhe uma criação sua e Dorian também reconhecia que fora Henry quem lhe despertara o "desejo desenfreado de conhecer todas as coisas da vida”. (WILDE, 2000, p. 35).

\section{CONSIDERAÇÕES FINAIS}

Começamos este trabalho indagando se as transformações sofridas pelo retrato de Dorian seriam fruto de algo sobrenatural, ou apenas resultado de como seu receptor o lia. Com base na teoria da recepção, consideramos que o retrato de Dorian não pode ser visto como uma obra fechada, tal como o seria dentro da perspectiva da fenomenologia, segundo a qual a obra tem uma essência captada pela consciência humana, e esta essência seria o sentido atribuído pelo o autor 
no ato de confecção da obra - ideia esta tida pelo pintor Basil, no início do romance.

Acreditamos que a leitura do retrato se deu em um movimento de interpretações onde, como diz Eagleton, nossas concepções são violentadas e transgredidas de tal modo que "se modificarmos o texto com nossas estratégias de leitura, ele simultaneamente nos modifica". (EAGLETON, 1997, p. 108).

Para Iser (1997, p. 29), "o significado do texto resulta de uma retomada ou apropriação daquela experiência que o texto desencadeou e que o leitor assimila e controla segundo suas próprias disposições". No caso de Dorian, isso foi levado ao extremo, a arte insuflou a vida de tal modo que, quando se viu sem controle, quando percebeu que mesmo a prática de boas ações não cessava a deformação de sua imagem no retrato, suicidou-se.

Por fim, podemos considerar o suicídio de Dorian como o momento da queda das máscaras ${ }^{4}$, em que o leitor confirma seu enredamento neste, como diz Iser, fingimento que é a literatura. Podemos entrever também o autodesnudamento, espaço da evidenciação de que "o mundo representado no texto deve ser visto apenas como se fosse um mundo, embora não seja" (ISER, 1997, p. 69), e, assim, Dorian Gray concretiza diante de

\footnotetext{
${ }^{4}$ Fábio Durão, professor livre-docente de Teoria Literária na UNICAMP, menciona a ideia do romance $O$ retrato de Dorian Gray representar um cenário de experiências estéticas. Não é por acaso que Dorian se apaixona por uma atriz e se desinteressa por ela justamente quando a moça diz que não irá mais interpretar, que será ela mesma dali em diante. Segundo Fabio Durão, o romance traz o núcleo da concepção estética, em que a máscara é mais autêntica do que uma individualidade própria, sendo extremamente entediante lidar com o sujeito que é ele mesmo o tempo todo. Disponível em: $<<$ https://www.youtube. com/watch?v=7SzvRSJmOjI>>. Acesso em: 20 dez. 2015.
}

seu retrato o que prenunciou no início do romance: "quando eu verificar que estou a envelhecer, suicido-me”. (WILDE, 2000, p. 21).

\section{REFERÊNCIAS}

DERRIDA, Jacques. Essa estranha instituição chamada literatura: uma entrevista com Jacques Derrida. Tradução: Marileide Dias Esquerda. Belo Horizonte: Editora UFMG, 2014.

EAGLETON, Terry. Fenomenologia, hermenêutica, teoria da recepção. In:

Teoria da literatura: uma introdução. 3.ed. São Paulo: Martins Fontes, 1997, p. 75-123.

ISER, Wolfgang. Teoria da recepção: reação a uma circunstância histórica. In: ROCHA, João Cezar de Castro (org.). Teoria da ficção: indagações à obra de Wolfgang Iser. Tradução: Bluma Waddington Vilar, João Cezar de Castro Rocha. Rio de Janeiro: EduERJ, 1999, p. 20-33. . O fictício e o imaginário. In: ROCHA, João Cezar de Castro (org.). Teoria da ficção: indagações à obra de Wolfgang Iser. Tradução: Bluma Waddington Vilar, João Cezar de Castro Rocha. Rio de Janeiro: EduERJ, 1999, p. 65-77.

WILDE, Oscar. O retrato de Dorian Gray. Tradução: Maria de Lurdes Souza Ruivo. Disponível em:<http://www. colegiosantosanjos.g12.br/downloads/ livros/O_Retrato_de_Dorian_Gray.pdf>. Acesso em: 20 nov. 2015.

Recebido para publicação em 05 mar. 2016. Aceito para publicação em 25 maio 2016. 